\title{
Formulation and Evaluation of Liquid Filled Hard Gelatin Capsule of Febuxostat
}

\author{
Sonar S. P1*, Gondkar S.B' ${ }^{1}$, Saudagar R.B ${ }^{2}$ \\ ${ }^{1}$ Department of Pharmaceutics, R. G. Sapkal College of Pharmacy, Anjaneri, Nashik-422213, Maharashtra, India \\ ${ }^{2}$ Department of Pharmaceutical Chemistry, R. G. Sapkal College of Pharmacy, Anjaneri, Nashik- 422213, Maharashtra, India.
}

\begin{abstract}
Liquid filled hard gelatin capsule are well recognized as a solid dosage form for convenient administration of drugs orally in a liquid form. This liquid composition available help the most challenging drug compounds in capsules has increased significantly in recent years. The drugs which have low solubility, poor bioavailability, low melting point, critical stability are the perfect candidate for liquid filling in capsule. The current study presents the formulation aspects, filling and sealing aspects of capsule, evaluation parameters of the liquid filled hard gelatin capsule using Febuxostat as drug, oils (Arachis oil, Coconut oil, Olive oil) as solvents, Glyceryl monostearate as solubilizing agent, Butylated hydroxy toluene as antioxidant, Methyl paraben \& Propyl paraben as preservatives. A capsule formed F3 formulation shows maximum drug release and drug content among all the formulations.
\end{abstract}

Keywords: Liquid filled hard gelatin capsule, Febuxostat, Arachis oil, Coconut oil, Olive oil, Glyceryl monostearate, Butylated hydroxy toluene, Methyl paraben, Propyl paraben.

Article Info: Received 23 June 2019; Review Completed 10 Aug 2019; $\quad$ Accepted 19 Aug 2019; Available online 15 Sep 2019

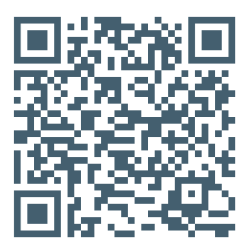

\section{Cite this article as:}

Sonar SP, Gondkar SB, Saudagar RB, Formulation and Evaluation of Liquid Filled Hard Gelatin Capsule of Febuxostat Journal of Drug Delivery and Therapeutics. 2019; 9(5):105-109 http://dx.doi.org/10.22270/jddt.v9i5.3579

*Address for Correspondence:

Sonar Shivani Prashant, Department of Pharmaceutics, R.G. Sapkal College of Pharmacy, Anjaneri, Nashik 422213

Maharashtra, India.

\section{INTRODUCTION}

Liquid filled hard gelatin capsule are well recognized as a solid dosage form for convenient administration of drugs orally in a liquid form. Liquid filled capsule technology can be used for liquid and semisolid fills in hard gelatin or HPMC capsule with or without banding. This liquid composition available help the most challenging drug compounds in capsules has increased significantly in recent years. In particular it is possible to solubilize many drug compounds in a micro emulsion pre-concentrate inside the hard gelatin capsules such that on subsequent dispersion in the gastro intestinal tract, the drug remains in solution. It is considered that this technology can make a significant contribution to the development of efficacious pharmaceutical products by providing the flexibility to rapidly develop and test in house formulation when small quantities of drug is available. Liquid-fill hard gelatin capsule technology was established in the early 1980s as an alternative to soft gelatin capsules This technology is mostly suitable for insoluble compounds, highly potent compounds. Once the capsule is filled, they are sealed by spraying small amount of Water/ethanol mixture at the cap and body interface followed by gentle warming to fuse the two parts of capsule together or by band sealing of capsule with gelatin or cellulose. ${ }^{1}$

Febuxostat is a novel drug which is developed for the treatment of gout and hyperuricemia. As an inhibitor of xanthine oxidase, it provides a selective and potent property compared with allopurinol.2 ${ }^{2}$ FXT acquired admission from the Food and Drug Administration (FDA) in 2009.It was the first new drug the FDA approved in 40 years, which was used for lowering the level of serum uric acid in vivo. ${ }^{3}$ In recent years FXT has acquired extensive attractions owing to its good therapeutic effect. FXT is a weak acid (PKa 3.42) ${ }^{4}$ which is practically insoluble in water and the solubility was about $12.9 \mu \mathrm{g} / \mathrm{ml}$ in water at $37^{\circ} \mathrm{C} .5$ The bioavailability of FXT is approximately $80 \%$ and the half-life is about 5-8 hrs. $^{6}$ FXT is classified as a Biopharmaceutics Classification System (BCS) II drug due to its low solubility and high permeability. ${ }^{7}$ In general, the primary problem of formulation for BCS II drugs is how to improve the dissolution. Water solubility is the main factor that influences the bioavailability of this kind of drug. ${ }^{8}$ Although FXT shows good pharmaceutical behavior, the improvement of aqueous solubility would be conducive to the absorption process. ${ }^{9}$ Poor aqueous solubility could be 
improved in many ways, such as nanosuspension, solid dispersion, co-crystals, hydrates and salts, liquid formulations using oil as solvent. 10-12 The purpose of the present study was to provide a novel way to improve the aqueous solubility and in vivo bioavailability of FXT.

\section{Drug categories suitable for Liquid filled capsules}

1. Drugs with Poor bioavailability:

The bioavailability of the poorly water-soluble drugs can be significantly enhanced when formulated as a liquid in a hard gelatin capsule. ${ }^{13,14}$

\section{Drugs with Low melting point:}

Materials having low melting points or are liquid at room temperature have some problems when formulating as dry powders, often requiring high concentrations of excipient to avoid processing problems. ${ }^{15}$

\section{Potent drugs:}

Drugs in this category present two main challenges; content uniformity and cross-contamination and worker protection. 16,17

\section{Sustained release drug candidates:}

By choosing an appropriate excipient the release rate of an active ingredient can be modified. E.g., soybean oil and glyceryl monostearate. 18

The objective of study was to prepare Liquid filled hard gelatin capsule of Febuxostat which can be useful in Gout therapy. Liquid filled hard gelatin capsule prepared by simple mixing oils (Arachis oil, Coconut oil, Olive oil), Glyceryl monostearate, Butylated hydroxy toluene, Methyl paraben \& Propyl paraben as preservatives and filled into capsule of size 00 . It was sealed by banding technique using $15 \% \mathrm{w} / \mathrm{v}$ gelatin solution. The prepared capsules were evaluated for weight variation, content uniformity, disintegration, dissolution studies, release kinetics and stability studies. The formulation was compared with marketed formulation of Febuxostat (Febucip 40).

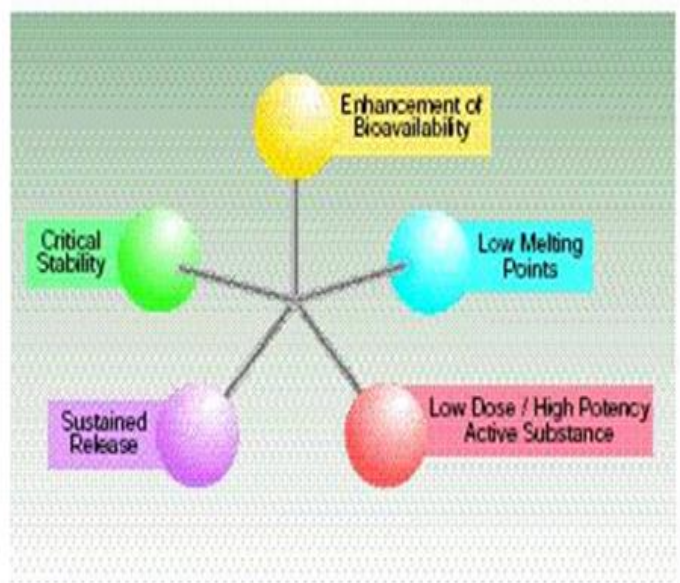

Figure 1. Reasons for Formulating Drugs as Liquid Dosage

\section{MATERIALS \& METHODS}

Febuxostat as a gift sample from Ami Lifesciences, Vadodara, Arachis oil from Modern industries, Sinnar, Olive oil from Evonik, Kolkata, Coconut oil, GMS from LOBA CHEMIE PVT LTD, Mumbai, BHT, Methyl \& Propyl paraben from Research lab fine chem industries, Mumbai.

\section{Preparation of Liquid filled hard gelatin capsule}

Weigh Febuxostat 40mg and dissolved in $1 \mathrm{ml}$ Arachis, Coconut \& Olive oil. Add GMS, BHT, Methyl \& Propyl paraben. Prepared formulation was filled into capsule size 00 . The capsule was sealed by banding technique using $15 \% \mathrm{w} / \mathrm{v}$ gelatin solution.

Table 1. Composition of Febuxostat Liquid filled Hard gelatin Capsule

\begin{tabular}{|c|c|c|c|c|c|c|c|c|c|}
\hline $\begin{array}{c}\text { Ingredients } \\
\begin{array}{c}\text { Febuxostat } \\
\text { (mg) }\end{array}\end{array}$ & F1 & F2 & F3 & F4 & F5 & F6 & F7 & F8 & F9 \\
\hline $\begin{array}{c}\text { Arachis Oil } \\
\text { (ml) }\end{array}$ & 1 & 1 & 1 & - & - & - & - & - & - \\
\hline $\begin{array}{c}\text { Coconut Oil } \\
\text { (ml) }\end{array}$ & - & - & - & 1 & 1 & 1 & - & - & - \\
\hline $\begin{array}{c}\text { Olive Oil } \\
\text { (ml) }\end{array}$ & - & - & - & - & - & - & 1 & 1 & 1 \\
\hline $\begin{array}{c}\text { GMS } \\
\text { (mg) }\end{array}$ & 10 & 15 & 20 & 10 & 15 & 20 & 10 & 15 & 20 \\
\hline $\begin{array}{c}\text { BHT } \\
\text { (mg) }\end{array}$ & 1 & 1 & 1 & 1 & 1 & 1 & 1 & 1 & 1 \\
\hline $\begin{array}{c}\text { Methyl:Propyl } \\
\text { Paraben (mg) }\end{array}$ & $\begin{array}{c}0.2 \\
(1: 1)\end{array}$ & $\begin{array}{c}0.2 \\
(1: 1)\end{array}$ & $\begin{array}{c}0.2 \\
(1: 1)\end{array}$ & $\begin{array}{c}0.2 \\
(1: 1)\end{array}$ & $\begin{array}{c}0.2 \\
(1: 1)\end{array}$ & $\begin{array}{c}0.2 \\
(1: 1)\end{array}$ & $\begin{array}{c}0.2 \\
(1: 1)\end{array}$ & $\begin{array}{c}0.2 \\
(1: 1)\end{array}$ & $\begin{array}{c}0.2 \\
(1: 1)\end{array}$ \\
\hline
\end{tabular}

Evaluation parameters of liquid filled capsules $19,20,21,22,23,24,25,26$

\section{Weight variation test}

Fill the capsule shell with formulation. Take 20 capsules and weight of individual capsule should be noted and average weight is calculated. Not more than two individual weight deviates from average weight. (15)

2.Content uniformity:
Intact capsule was weighed. The capsule was opened without losing any part of the shell and contents were removed as completely as possible. The shell was washed with ether or other suitable solvent and the shell allowed to stand until the odour of the solvent was no longer detectable. By using UV Spectroscopy content uniformity was calculated.

\section{Disintegration:}

The capsules were placed in the basket rack assembly, which is repeatedly immersed 30 times per minute into a CODEN (USA): JDDTAO 
thermostatically controlled fluid at $37^{\circ} \mathrm{C}$. To fully satisfy the test, the capsules should disintegrate completely into a soft mass having no palpably firm core without any fragments of the gelatin shell. If one or two capsules fail the test should be repeated for additional of 12 capsules. Then not fewer than 16 of the total 18 capsules tested should disintegrate completely.

\section{Dissolution studies:}

Dissolution is a process by which the disintegrated solid solute converted into solution. The test determines the time required for a definite percentage of the drug in capsules to dissolve under specified conditions. The release of drug was determined using a dissolution apparatus of USP type II paddle at $50 \mathrm{rpm} 900 \mathrm{ml}$ of $0.1 \mathrm{~N} \mathrm{HCl}$ solution was used as a dissolution media and maintained at temp $37.5^{\circ} \mathrm{C}$ for $60 \mathrm{~min}$ The dissolution study of liquid filled hard gelatin capsule was compared with marketed formulation of Febuxostat (Febucip 40). The data was subjected for kinetic model. The kinetic modeling of drug release and the model with the higher correlation coefficient i.e. higher $\mathrm{R}^{2}$ was considered to be the best fit model.

\section{Stability studies:}

Preliminary stability of the best formulation obtained by investigating its Physical characteristics and drug content and drug release after storage at stressed conditions. LFHGC was stored at $40 \pm 2^{\circ} \mathrm{C} \& 75 \pm 5 \% \mathrm{RH}$ for a period of 1 month. The Physical characteristics and drug content and drug release of the fresh (stored at room temperature) and stressed preparations are compared to evaluate the stability and effect of aging.

\section{RESULT AND DISCUSSION}

\section{Weight variation}

The weight of each liquid filled capsule was taken on Electronic analytical balance and the weight variation was calculated as mean SD. Weight variation varies from $98.60 \pm 0.945$ to $102.3 \pm 2.210$.

\section{Content uniformity:}

Drug content of optimized batches were calculated by using liquid filled capsule containing $40 \mathrm{mg}$ of febuxostat. Three trials from each formulation are analyzed spectrophotometrically. The mean value and standard deviation of all the formulations are calculated. The drug content ranging from $97.05 \pm 2.155$ to $99.31 \pm 2.455$. The results indicated that in all the formulations the drug content is uniform. The studies also show that uniformity of content is in the range of $85-115 \%$.

\section{Disintegration:}

The capsules were placed in the basket rack assembly, which is repeatedly immersed 30 times per minute into a thermostatically controlled fluid at $37^{\circ} \mathrm{C}$. To fully satisfy the test, the capsules should disintegrate completely into a soft mass having no palpably firm core without any fragments of the gelatin shell. Limit of disintegration is $30 \mathrm{~min}$. The disintegration time ranging from $33.0 \pm 0.535$ to $38.0 \pm 1.1305$. The result indicated that all the formulations shows very less deviation in disintegration profile which may be because of the same size \& type of capsule shell used.

\section{Dissolution studies}

The release of drug was determined using a dissolution apparatus of USP type II paddle at $50 \mathrm{rpm} 900 \mathrm{ml}$ of $0.1 \mathrm{~N}$ $\mathrm{HCl}$ solution was used as a dissolution media and maintained at temp $37.5^{\circ} \mathrm{C}$ for $60 \mathrm{~min}$. In-vitro dissolution study shows $\%$ cumulative drug release ranging from $80.10 \pm 0.80$ to 98.57 \pm 0.993 . Maximum release i.e. $98.57 \%$ for F3 formulation this could be attributed due to higher concentration of GMS in the formulation.

In vitro dissolution profile of liquid filled capsule (F3) and Marketed formulation (Febucip 40) are compared together. Liquid filled capsule of febuxostat shows more \% drug release than the marketed formulation which may be because of undissolved amount of the drug present in marketed formulation even after $60 \mathrm{~min}$.

\section{Kinetics of drug release:}

To analyze the mechanism of drug release of the optimized batch (F3) of the liquid filled hard gelatin capsule was obtained from the drug release studies which was subjected to mathematical model of korsemeyer's peppas. The correlation coefficient $\left(\mathrm{r}^{2}\right)$ was used as an indicator for the best fitting for each of the models. The table 7 shows the Kinetics treatment for the optimized formulation(F3). The drug release mechanism of liquid filled hard gelatin capsule of febuxostat was shown below.

\section{Stability studies:}

Optimized formulation $\mathrm{F} 3$ at $40 \pm 2{ }^{\circ} \mathrm{C}, 75 \pm 5 \% \mathrm{RH}$ was found to be stable up to 30 days. There was no significant change in drug content, visual appearance i.e. changes in color. All Formulations stored at elevated temperature showed very slight changes in disintegration time and drug content and drug release.

Table 2. Evaluation of Febuxostat Liquid filled Hard gelatin Capsule

\begin{tabular}{|c|l|l|l|c|}
\hline Sr.No. & $\begin{array}{c}\text { Formulation } \\
\text { code }\end{array}$ & $\begin{array}{c}\text { Average weight } \\
\mathbf{( m g )} \\
\text { Mean } \pm \text { SD }\end{array}$ & \multicolumn{1}{|c|}{$\begin{array}{c}\text { Drug content } \\
\mathbf{( \% )} \\
\text { Mean } \pm \text { SD }\end{array}$} & $\begin{array}{c}\text { Disintegration } \\
\text { time (min) } \\
\text { Mean } \pm \text { S.D. }\end{array}$ \\
\hline $\mathbf{0 1}$ & F1 & $98.70 \pm 0.807$ & $97.10 \pm 2.160$ & $36.7 \pm 1.141$ \\
\hline $\mathbf{0 2}$ & F2 & $99.0 \pm 0.894$ & $98.35 \pm 2.350$ & $34.2 \pm 0.580$ \\
\hline $\mathbf{0 3}$ & F3 & $98.60 \pm 0.945$ & $99.31 \pm 2.455$ & $33.0 \pm 0.535$ \\
\hline $\mathbf{0 4}$ & F4 & $101.75 \pm 1.512$ & $97.05 \pm 2.155$ & $37.3 \pm 1.230$ \\
\hline $\mathbf{0 5}$ & F5 & $100.5 \pm 1.554$ & $98.20 \pm 2.310$ & $35.0 \pm 0.860$ \\
\hline $\mathbf{0 6}$ & F6 & $102.10 \pm 1.575$ & $99.08 \pm 2.425$ & $33.3 \pm 0.550$ \\
\hline $\mathbf{0 7}$ & F7 & $101.0 \pm 2.120$ & $97.40 \pm 2.425$ & $38.0 \pm 1.1305$ \\
\hline $\mathbf{0 8}$ & F8 & $102.3 \pm 2.210$ & $98.71 \pm 2.390$ & $35.5 \pm 0.875$ \\
\hline $\mathbf{0 9}$ & F9 & $99.5 \pm 2.090$ & $99.15 \pm 2.433$ & \\
\hline
\end{tabular}


Table 3. Dissolution study of liquid filled hard gelatin capsule of Febuxostat

\begin{tabular}{|c|c|c|c|c|c|c|c|c|c|}
\hline \multirow{2}{*}{$\begin{array}{l}\text { TIM } \\
\text { E } \\
\text { IN } \\
\text { MIN }\end{array}$} & \multicolumn{9}{|c|}{$\%$ CUMULATIVE DRUG RELEASE \pm S.D } \\
\hline & F1 & F2 & F3 & F4 & F5 & F6 & F7 & F8 & F9 \\
\hline 10 & $\begin{array}{c}52.80 \\
\pm \\
0.315\end{array}$ & $\begin{array}{l}55.7 \\
t_{0.401}\end{array}$ & $\begin{array}{l}61.5 \\
\pm \\
0.522\end{array}$ & $\begin{array}{l}43.6 \\
\pm \\
0.478\end{array}$ & $\begin{array}{c}59.8 \\
\pm \\
0.309\end{array}$ & $\begin{array}{c}63.2 \\
\pm \\
0.510\end{array}$ & $\begin{array}{l}41.0 \\
\pm \\
0.620\end{array}$ & \begin{tabular}{|l}
54.8 \\
\\
0.711
\end{tabular} & $\begin{array}{l}50.6 \\
\\
0.840\end{array}$ \\
\hline 20 & $\begin{array}{l}63.34 \\
\pm \\
0.300\end{array}$ & $\begin{array}{l}69.94 \\
\pm \\
0.501\end{array}$ & $\begin{array}{l}77.85 \\
= \\
0.650\end{array}$ & $\begin{array}{l}55.95 \\
\pm \\
0.670\end{array}$ & $\begin{array}{l}70.18 \\
\pm \\
0.550\end{array}$ & $\begin{array}{l}75.10 \\
\pm \\
0.525\end{array}$ & $\begin{array}{l}50.03 \\
\pm \\
0.740\end{array}$ & $\begin{array}{l}65.51 \\
\pm \\
0.415\end{array}$ & $\begin{array}{l}1.60 \\
\pm \\
0.190\end{array}$ \\
\hline 30 & $\begin{array}{l}71.43 \\
= \\
0.595\end{array}$ & $\begin{array}{l}75.49 \\
\pm \\
0.550\end{array}$ & $\begin{array}{l}34.21 \\
\pm .830\end{array}$ & $\begin{array}{l}62.10 \\
\pm \\
0.250\end{array}$ & $\begin{array}{l}77.28 \\
\pm \\
0.610\end{array}$ & $\begin{array}{l}81.25 \\
\pm \\
0.826\end{array}$ & $\begin{array}{l}56.54 \\
= \\
0.785\end{array}$ & $\begin{array}{l}72.30 \\
\pm \\
0.540\end{array}$ & $\begin{array}{l}68.50 \\
\pm \\
0.490\end{array}$ \\
\hline 40 & $\begin{array}{l}79.10 \\
\pm \\
0.670\end{array}$ & $\begin{array}{l}35.51 \\
\pm \\
0.880\end{array}$ & $\begin{array}{l}90.65 \\
\pm 0.940\end{array}$ & $\begin{array}{l}70.48 \\
\pm \\
0.560\end{array}$ & $\begin{array}{l}84.59 \\
\pm \\
0.855\end{array}$ & $\begin{array}{l}89.69 \\
\pm \\
0.895\end{array}$ & $\begin{array}{l}64.80 \\
\pm \\
0.343\end{array}$ & $\begin{array}{l}78.90 \\
\pm \\
0.630\end{array}$ & $\begin{array}{l}75.27 \\
\pm \\
0.534\end{array}$ \\
\hline 50 & $\begin{array}{l}84.72 \\
\pm \\
0.861\end{array}$ & $\begin{array}{l}39.92 \\
\pm \\
0.900\end{array}$ & $\begin{array}{l}94.85 \\
\pm \\
0.873\end{array}$ & $\begin{array}{l}79.20 \\
\pm \\
0.685\end{array}$ & $\begin{array}{l}90.04 \\
\pm \\
0.911\end{array}$ & $\begin{array}{l}93.80 \\
\pm \\
0.965\end{array}$ & $\begin{array}{l}73.59 \\
\pm \\
0.651\end{array}$ & $\begin{array}{l}33.82 \\
\pm \\
0.775\end{array}$ & $\begin{array}{l}85.10 \\
\pm \\
0.870\end{array}$ \\
\hline 60 & $\begin{array}{l}88.51 \\
\pm \\
0.795\end{array}$ & $\begin{array}{l}95.17 \\
\pm \\
0.971\end{array}$ & $\begin{array}{l}98.57 \\
\pm \\
0.993\end{array}$ & $\begin{array}{l}84.38 \\
\pm \\
0.842\end{array}$ & $\begin{array}{l}94.49 \\
\pm \\
0.964\end{array}$ & $\begin{array}{l}96.35 \\
\pm \\
0.984\end{array}$ & $\begin{array}{l}30.10 \\
\pm \\
0.805\end{array}$ & $\begin{array}{l}39.14 \\
\pm \\
0.890\end{array}$ & $\begin{array}{l}\mid 1.85 \\
\pm \\
0.924\end{array}$ \\
\hline
\end{tabular}

Table.4: In vitro dissolution profile of liquid filled capsule (F3) and Marketed formulation (Febucip 40)

\begin{tabular}{|c|c|c|c|}
\hline Sr.no. & Time (min) & \multicolumn{2}{|c|}{$\%$ Drug Release } \\
\hline & & $\begin{array}{c}\text { Liquid filled capsule } \\
\text { (F3) }\end{array}$ & $\begin{array}{c}\text { Marketed formulation } \\
\text { (Febucip 40) }\end{array}$ \\
\hline 1 & 10 & 61.53 & 28.524 \\
\hline 2 & 20 & 77.85 & 35.690 \\
\hline 3 & 30 & 84.21 & 46.327 \\
\hline 4 & 40 & 90.65 & 59.016 \\
\hline 5 & 50 & 94.85 & 68.128 \\
\hline 6 & 60 & 98.57 & 70.269 \\
\hline
\end{tabular}

Table 5. $\mathbf{R}^{2}$ values for Korsemeyer's peppas release kinetics

\begin{tabular}{|c|c|}
\hline Formulation Code & F3 \\
\hline $\mathrm{R}^{2}$ value & 0.985 \\
\hline
\end{tabular}




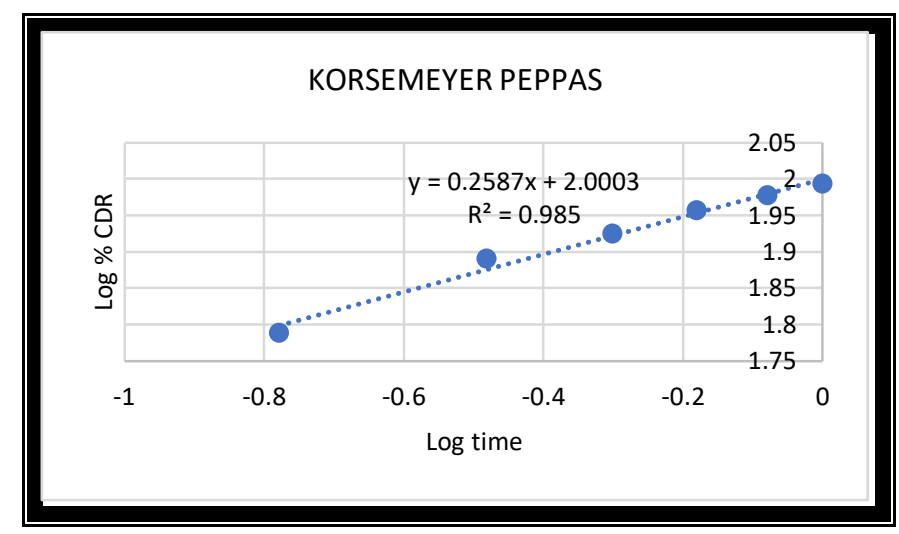

Table 6. Stability data for F3 formulation

\begin{tabular}{|c|c|c|c|}
\hline $\begin{array}{l}\text { SR. } \\
\text { NO }\end{array}$ & OBSERVATION & $\begin{array}{c}\text { BERFOR STABILITY } \\
\text { TESTING }\end{array}$ & $\begin{array}{l}\text { AFTER STABILITY } \\
\text { TESTING }\end{array}$ \\
\hline 1. & Visual appearance \\
(Color changes) & No change & No change \\
\hline 2. & Drug content & $99.31 \%$ & $99.28 \%$ \\
\hline 3. & Disintegration time & $33 \mathrm{~min}$ & $34 \mathrm{~min}$ \\
\hline & Drug release & $98.57 \%$ & $98.45 \%$ \\
\hline
\end{tabular}

\section{CONCLUSION}

Liquid filled hard gelatin capsule of Febuxostat was prepared using different oils. The drug content \& drug release was found to be maximum in the capsule containing Arachis oil \& maximum concentration of Glyceryl monostearate (F3). From the obtained data of our experimentation, liquid filled hard gelatin capsule of Febuxostat can be a good alternative to conventional uncoated marketed formulation with possible improvements in the absorption of the drug \& subsequent bioavailability.

\section{ACKNOWLEDGEMENT}

The author wishes to acknowledge Ami Lifesciences, Vadodara for providing a gift sample of febuxostat for the research work.

\section{REFERENCES}

1.Thamada N*, Satyavathi D, Gupta S, Kumar D. Challenges and opportunity in encapsulation of Liquid filled hard gelatin over soft gelatin capsules - An innovative technology. International Journal of Institutional Pharmacy and Life Sciences; 2014;4(3):100-113.

2. Ding $X$, Zhang $Q$, Wang Z, et al. Development and validation of liquid chromatography-mass spectrometry method for determination of febuxostat in rat plasma and its application. Lat Am J Pharm 2012;31(2):321-325.

3.Wang H, Deng P, Chen X, et al. Development and validation of a liquid chromatography-tandem mass spectrometry method for the determination of febuxostat in human plasma. Biomed Chromatogr 2013;27(1):34-38.

4. Shah VP, Amidon GL. G.L.Amidon, H. Lennernas,V.P. Shah, and J.R. Crison.A theoretical basis for a biopharmaceutic drug classification: the correlation of in vitro drug product dissolution and in vivo bioavailability, Pharm Res 12, 413-420, 1995 - backstory of BCS. AAPS J 2014;16(5):894-898.

5. Khosravan R, Grabowski B, Wu JT, et al. Effect of food or antacid on pharmacokinetics and pharmacodynamics of febuxostat in healthy subjects. Br J Clin Pharmacol 2008;65(3):355-363.
6. Sharma M, Parmar K, Baria A, et al. Gastro retentive tablet of febuxostat: formulation, drug release dynamics and factorial design. World J Pharm Res 2015;4(1):1063-1082.

7. Dass R,Jaiswal S,Gupta GD.Formulation and evaluation of febuxostat fast disintegrating tablet.IAJPR2014;4(6):29282936.

8. Kawabata Y, Wada K, Nakatani M, et al. Formulation design for poorly water-soluble drugs based on biopharmaceutics classification system: basic approaches and practical applications. Int J Pharm 2011;420(1):1-10.

9. Dwivedi SD. Substantially pure salts of febuxostat and processes for preparation thereof. United States. 20130190366A1 [P]. 2013.

10. Domingos S, André V, Quaresma S, et al. New forms of old drugs: improving without changing. J Pharm Pharmacol 2015;67(6):830-846.

11. Ahuja BK, Jena SK, Paidi SK, et al. Formulation, optimization and in vitro-in vivo evaluation of febuxostat nanosuspension. Int J Pharm 2015;478(2):540-552.

12. Pandya RB, Mehta TA, Gohel MC. Solid dispersion adsorbate-a novel technique for dissolution enhancement of febuxostat. IJPSR 2015;6(11):4236-4242.

13.Ghirardi P, Catenazzo G, Mantero O, Merotti GC and Marzo C. J. Pharm. Sci;1977;66(2): 267-269.

14. Walker SE, K. Bedford, and T. Eaves, British patent; 1980; 30 572-226.

15. Duerr M, Fridolin $\mathrm{HU}$ and Gneuss KD, Acta Pharm. Technology;1983; 29 (3): 245-251.

16. Kovarik JM, Mueller EA, Van JB, Tetzloff W and Kutz K, J. Pharm. Sci.; 1994;83: 444-446.

17. Patent, Oil-Free Pharmaceutical compositions containing cyclosporin A, WO 93/20833, 1993.

18. Hawley AR, Rowley G, Lough WJ, Chatham SM, Drug Devel. Ind. Pharm.; 1992;18 (16): 1719.

19. Reddy B, Deepthi A, Ujwala P. Capsule production- Industrial view. Journal of global trends in pharmaceutical sciences;2012;3(4):887-909.

20. Balivada R. Solubilized formulation and evaluation of Liquid filled hard gelatin capsules of Estrogen receptor modulator drug. International journal of research in pharmacy and chemistry; 2011;1(4):1046-1057.

21. P Tripura Sundari, Swetha G. Formulation and evaluation of SMEDDS containing febuxostat by employing coconut oil and labrasol as oil and surfactant system. International Journal of 
Research in Pharmacy and Pharmaceutical Sciences;March 2018;3(2):48-53.

22. V. Deva Prasad. Formulation and modifying drug release from Hard and Soft Gelatin Capsules for Oral drug delivery. International Journal of Research and Development inPharmacy \& amp; Life Science; June-July;6(4):2663-2677.

23.Indian Pharmacopoeia. Government of India Ministry of Health \& family Welfare. Published by the Indian Pharmacopoeia Commission, Ghaziabad. 2014; Volume I; 251-257.
24. Radhakant G., Himankar B. et.al. Application of Mathematical Models in Drug Release Kinetics of Carbidopa \& Levodopa ER Tablets. Journal of Developing Drugs; 2017; 6(2);1-8.

25. Rina Praveen H., Siva P., Formulation and evaluation of liquid filled hard gelatin capsule of immediate release Alprazolam. International Journal of Pharmaceutical Development \& Technology;2017;7(2);59-61

26. Roopa rani B. Solubilized formulation and evaluation of liquid filled hard gelatin capsules of Estrogen receptor modulator drug. International Journal of Research in Pharmacy and Chemistry;2011;1(4);1046-1057 